UDC: 811.432.2'37; 811.432.2'36

\title{
THE MEANING OF THE YE FORMS IN BASSE MANDINKA
}

\author{
ALEXANDER ANDRASON ${ }^{1}$ \\ Stellenbosch University, Faculty of Humanities \\ Department of Ancient Studies \\ Stellenbosch, South Africa
}

U ovom radu se analizira semantički sadržaj gramova formiranih oblikom ye u varijanti jezika mandinka koja se govori u Baseu i okolnim selima u naistočnijem delu Gambije. Ove konstrukcije mogu se podeliti u dve grupe: tipovi $Y E_{1}$ i $Y E_{2}$ Kada je reč o varijanti $Y E_{1}$, naš materijal pokazuje da se ta konstrukcija koristi kao sadašnji perfekt (sa rezultativnim, inkluzivnim, iterativnim, iskustvenim, neodređenim i performativnim značenjem), prošlo vreme (svršeno, prosto i trajno), prošli perfekt i budući perfekt. U kondicionalima ova konstrukcija uvodi tri vrste značenja: hipotetičke aktivnosti, kontrafaktuelne ali još uvek moguće akcije i irealne kontrafaktuelne situacije u prošlosti. Kada se izvodi iz nekih glagola primanja, opažanja i osećanja, ova konstrukcija funkcioniše kao simultanorezultativno, stativno prosto sadašnje i buduće vreme. Takođe se sreće u izrekama gde ima vrednost univerzalnog ili habitualnog prezenta. Kada je reč o $Y E_{2}$ gramu, značenje je uvek modalno. Ova konstrukcija funkcioniše kao kohortativ, imperativ i jusiv. Ona, takođe, može iskazivati realno (sadašnjost-budućnost), ili irealno (prošlost) optativno značenje. Oblik $Y E_{2}$ ima snagu namernog subjunktiva u finalnim zavisnim rečenicama, kojim se izražavaju ciljevi i namere.

Ključne reči: afrička lingvistika, porodica jezika mande, manding jezici, glagolski sistem, semantika.

\section{INTRODUCTION}

Mandinka may be classified as the westernmost variety of the Manding cluster (Wilson 2000:109) which, in turn, forms a part of the Western branch of the Mande family (Kastenholz 1996:281, Vydrine, Bergman \& Benjamin 2000 and Williamson \& Blench 2000). Manding, itself, includes various regional variants or dialects such as

1 Kontakt podaci (Email): aleksand@hi.is 
Bambara (employed especially in Mali), Malinké (used in Guinea) and finally Mandinka an idiom widely spoken in Gambia, Senegal and Guinea Bissau with a total number of speakers amounting, as for the year 2006, to almost one and a half million (Lewis 2009).

The use of Mandinka in Gambia, as well as in other countries, ${ }^{2}$ is almost exclusively colloquial. However, in recent times, the language has acquired a more respectful status due to the standardization of its spelling, completed in A practical Orthography of Gambian Mandinka (1988 and 1993) ${ }^{3}$ and subsequently employed in Mandinka English Dictionary (1988 and 1995) and in translations of some important Christian and Muslim religious texts, e.g.: Kamben Kutoo ('New Testament' 1989), Kamben Kotoo ('Old Testament' 1998) and Selections from the Writings of the Promised Messiah (1988). This constant endeavor for homogenizing or standardizing the tongue and, consequently, for its adjustment to a literary production - together with a timid but yet increasing appearance of Mandinka in television, radio and the Internet - has indisputably improved the socio-political position of the idiom.

The description of the Mandinka language, although greatly advanced by several important articles and some insightful grammar books (cf. for instance, Rowlands 1959 and (reissels 1983), still include areas which could be studied in a more exhaustive manner. One of them is the semantics of verbal constructions.

The present paper-meeting theabove-mentioned demand for further grammatical analyses - aims at providing a detailed examination of the semantic load of a verbal category of Mandinka, labeled in accordance with its most distinctive morphological marker, the $Y E$ form: in order to form the construction, exemplified in (1), one employs the lexeme ye (cf. however, the $\eta a$ and $\eta a ̀$ markers are also frequently used in the first person singular and plural).

\section{(1) A ye faloo san \\ he $\mathrm{YE}^{5}$ donkey buy \\ He bought a donkey}

The formation - invariably transitive and positive (its negative form employs the lexeme man instead of ye or na ${ }^{6}$ - has been classified in some general grammar books or papers dedicated to other linguistic phenomena as an aorist tense (Macbrair 1842: 15), a stative (Creissles 1983) or a perfective-completive aspect (Creissels 2008: 77, 2010a: 3, 2010b: 3; cf. also Rowlands 1959, Spears 1965, Long 1971 and Mandinka Learning Manual 2002). More specifically, Macbrair (1842: 15-16) proposes that the construction describes past and present actions as well as states which exist from a certain instant in the past to the present day, or more accurately, to the moment which is simultaneous to the main reference time. It approximates, thus, a past tense, present tense, perfect and pluperfect. According to Creissels (1983), the YE affirmative

2 We will focus on Gambian Mandinka given the fact that, as will be explained, our evidence has been collected in the Upper River Region, an Eastern part of that country.

3 This spelling convention has likewise been maintained in the present paper.

4 The relevant $Y E$ verbal forms will be given in bold type.

5 All markers of the YE formation - either ye or na - will be glossed as YE.

6 The negative variant of the sentence quoted in example (1) would be A man faloo san 'He did not buy a donkey'. 
transitive stative marker may apply to present and past time spheres. It introduces both completive actions and ongoing states, being furthermore employed to convey the meaning of future eventuality. A similar description may be found in Mandinka Learning Manual (2002: 14-15) where the YE construction is said to be an aspectual form which denotes a completed action or a state which is presently actual, corresponding to the English simple past, simple present and perfect tenses. Finally, Gamble (1987: 17-18), Colley (1995: 9, 12 and 15) and Drammé (2003: 47 and 50) specify the value of the YE form as equivalent to past and present tenses.

It should be noted that the marker ye may also be used to derive another verbal expression, which - in contrast to the previously described $Y E$ gram - can be both transitive and intransitive (cf. example 2) and which is furthermore negated by employing the entity kana instead of man. ${ }^{7}$ This construction has been viewed as prototypically modal, a type of a subjunctive (Creissles 1983 and Wilson 2000). Its meaning includes injunctive, optative, suggestive or purposive values (ibid.) or corresponds to an imperative-exhortative category (Gamble 1987: 18 and 22), equivalent to the English expressions such as let us, shall I, so that I shall/I can.

\section{(2) A ye naa! \\ he YE come \\ May he come!}

Our paper, yet devoted to the semantics of the two kinds of the YE constructions, does not study the values of these forms in what would be called Standard Mandinka, i.e. the normalized language used in grammar books and literary texts. The description of the properties of the $Y E$ gram is narrowed to Mandinka native speakers, residents of Basse, the capital of the Upper River Region, and of neighboring villages (Bassending, Manneh Kunda and Kaba Kama and Mansajang) in the easternmost part of the Gambia. Basse Mandinka, although profoundly similar to the standardized literary language, displays various divergences. ${ }^{8}$ For instance in Basse, the voiced velar stop [g] - absent in the "official" Mandinka - is regularly used and certain genitive or pronominal constructions may be formed with the postposition ye besides the standard form with la (for a complete review of differences, see Andrason forthcoming). ${ }^{9}$

In our discussion on the particularity of Basse Mandinka, we shall not overlook the fact that the territory where this variety is employed is dominated by other ethnic groups, in particular by Fulas and, much less importantly, by Serehules. This signifies that Fula and Serehule idioms prevail in various parts of the region although there are villages, a type of linguistic islands, with the Mandinka "supremacy". Finally, it should be acknowledged that in Basse and its proximities another regional variety of Manding is spoken:Jaahanka.

7 The negative variant of example (2) would be (fo) a kana naa! 'Let him not come!'

8 On the other hand, it should be emphasized that some of these dissimilarities are not limited to Basse Mandinka but, quite the opposite, may also be detected in other parts of Gambia.

9 Despite a number of differences, it may not be adequate to regard Basse Mandinka as a dialect of the standard language given the fact that the dissimilarities are mostly phonetic and lexical. On the other hand, it is evident that the issue of classifying a certain linguistic system as a dialect - or at a higher level, as a language - is not exclusively linguistic, but also depends on political, sociological and economic factors. 
As for the $Y E$ formation, Basse Mandinka admits three alternative variants of the marker employed for the first person singular or plural. Besides the standard form na, one may find by-forms such as na (very frequent), ne and ñe [ne] (these two varieties are relatively seldom met). Since the vernacular used in the capital of the Upper River Region and in its neighborhood is far from being a normalized consistent system, a unified solid language, it is not surprising that the acceptability of the four mentioned lexemes varies from one speaker to another. While some informants accepted all of them, giving the preference to $n a$, others regarded the form na as the most accurate yet being aware of the use of the auxiliary words $n a$, ne and ñe. ${ }^{10}$ Below, we offer the entire conjugational pattern of a gram derived by means of the ye entity, taking as an illustration the sentence motoo san 'buy a car (lit. in the inverse order, i.e. car + buy)':

\begin{tabular}{|c|c|c|}
\hline & Singular & Plural \\
\hline $1 p$ & na $($ na, ñe, ne) motoo san & 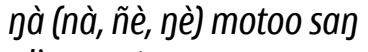 \\
\hline & i ye motoo san & ali ye motoo san \\
\hline $3 p$ & a ye motoo san & ìmotoo san \\
\hline
\end{tabular}

In the first person singular and plural, the form ye may also appear: nte (fanaa) ye motoo san 'I (also) bought the car'.

All the examples quoted in the present paper have been provided by ten native Mandinka speakers residing in Basse or in villages located in the vicinity of the Upper River Region capital. All of them participated as informants in an extensive field research which aimed at writing a grammar of Basse Mandinka (cf. Andrason forthcoming). Below we list these persons together with their age, occupation and place of residence: ${ }^{11} \mathrm{Keba}$ Suusoo (13 years old, primary school student, Bassending), Malik Suusoo (18, high school student, Bassending), Musa Yaffuneh (24, watchman, Basse), Lamin Manneh (25, university student, Manneh Kunda), Mamanding Sanyang (27, nurse assistant, Basse), Musa Sanneh (29, driver, Kaba Kama), Baba Kamara (30, teacher, Mansajang), Saikou Drammeh (44, nurse, Basse - originally from Serekunda, but has lived in Basse for ten years), Kumba Jallow (56, cook, Mansajang) and Mariama Mendi (32, nurse, Basse originally from Fulla Bantang) ${ }^{12}$.

It should be noted that all the examples have been video-recorded and systematically studied with the listed native speakers. In accordance with their methodological source, these examples may be arranged into three classes. The first group includes sentences spontaneously formulated by informants. The second assembles phrases which were produced on the request of the author. And the third class reflects examples which, although pronounced and - if necessary - reformulated by the native speakers, were inspired by passages found in standardized written texts, in particular in the Bible and in Islamic literature.

10 This also means that Basse Mandinka should be viewed as a combination - not a fusion - of several more local (limited to villages) or even personal realizations.

11 The list has been arranged according to the age of the informants.

12 The last two informants are entirely bilingual: Fula-Mandinka and Manjago-Mandinka. Their ethnic background is Fula and Manjago respectively. 


\section{EVIDENCE}

As it is the case in Standard Mandinka, the tense-aspect-taxis-mood (TATM) values of the locutions derived by means of the auxiliary ye may be divided into two major classes. The first group includes invariably transitive constructions which are negated substituting the entity ye by man (e.g., A man motoo san 'He did not buy the car'). As will be demonstrated in sections 2.1 and 3 below, this type of the YE construction hereafter labeled $Y E_{1}$ - provides meanings which parallel semantic properties displayed by the intransitive TA gram (observe that the negation of the TA formation also uses the particle man; cf. Andrason 2011b).

The other class embraces typically modal functions, which are usually referred to as subjunctive (cf. Creissels 1983 or Wilson 2000; for details see section 2.2). This variety - hereafter labeled as $Y E_{2}$ - offers two formal or syntactical properties which enable us to differentiate it from the variant mentioned previously. First, the $Y E_{2}$ locution may be virtually employed with all kinds of verbs either intransitive or transitive ones, in contrast to the $Y E_{1}$ form which is restricted to transitive constructions. Second, in order to negate the $Y E_{2}$ variant, the lexeme kana is used contrary to the element man which appears in the negation of the $Y E_{1}$ gram (e.g. Nà kana taa! 'Let us not go'). Additionally, the $Y E_{2}$ formation may be differentiated by placing the modal particle fo at the beginning of the sentence, before the subject (Fo a ye naa! 'May he come' / 'Let him come').

\subsection{VALUES OF THE YE 1 FORMATION}

The $Y E_{1}$ construction is commonly found with the force of a resultative present perfect: it portrays an already accomplished activity as relevant for the current situation. In other words, a formerly completed action has a patent effect on the preset state of affairs:

(3) a. Danko doron na motoo san

just only I-YE car buy

I have just bought the car (i.e. Now, I am an owner of the car)

b. A ye bundaa soron ne

he YE door close EMPH ${ }^{13}$

He has closed the door (i.e. The door remains closed)

c. Na a domo

I-YE it eat

I have eaten (i.e. I am done with the food)

d. I ye a ban?

you YE it finish

Have you finished?

The $Y E_{1}$ formation may also appear with the value of an inclusive perfect. In that case, it indicates that a situation or an activity has been holding without interruption from a certain - explicitly determined - point of time in the past to the present moment:

13 The lexeme le or ne (if following a nasal consonant) is an emphatic particle which will be glossed hereafter as EMPH. 
(4) a. Na motoo ñin soto kabirin 2001

I-YE car this have since 2001

I have had this car since 2001

b. Na sayikuloo ñin soto sanji saba

I-YE bicycle this have year three

I have had this bicycle for three years

c. Na ñin yaamaroolu bee muta le ka bo $n$ na dindinyaa waato la

I-YE this orders all EMPH from ${ }^{14} \mathrm{I}_{\text {of }}{ }^{15}$ childhood time at/with

I have kept all these orders from my youth up

d. Na a lon ne kabirin foloodulaa to

I-YE it know EMPH since beginning at

He has known it from the beginning

Likewise, the $Y E_{1}$ locution can express iterative resultative activities, functioning as an iterative perfect:

(5) a. Na ñin filimoo juubee siiñaa luulu

I-YE this film see time four

I have seen this film four times

b. Bii na wo ke siiñaa keme

today I-YE that do time hundred

Today, I have done it one hundred times

The $Y E_{1}$ gram is also commonly employed as an experiential perfect, indicating that the subject has performed a given activity - as a minimum - once during his or her life. Put differently, the person has an experience of carrying out the action expressed by the verb. In this sub-value of the perfect, the undertone of current relevance remains clearly recognizable, but on the contrary, the sense of resultativity is no longer available:

(6) a. Fo i ye nene sitajiyo min?

Whether you ever baobab.jus drink

Have you ever drunk baobab-jus?

b. Na bukoo ñin karan

I-YE book this read

I have read this book (it might have occurred at any time during my life time)

The $Y E_{1}$ gram can also function as an indefinite past (labeled alternatively 'indefinite perfect'), denoting indisputable past events and activities, without however specifying their temporal location in the past sphere in an overt manner, for instance by means of adverbial locutions: 
(7) Na a je marisewo to. A ye duuta luulu san. A ye ì samba suwo kono. I-YE him see market at. he YE mango five buy. he YE them bring home in I saw him at the market. He bought five mangos. He brought them home.

The $Y E_{1}$ form - approximating the category of a performative perfect (cf. Hebrew qatal and Arabic qatala, cf. Andrason 2011a) - is occasionally employed in order to perform certain acts rather than to describe a situation or an activity. This means that, if determined conventional circumstances are respected, the fact of uttering a given proposition with the verb in $Y E_{1}$ gram triggers a new state in the speaker's reality (cf. Austin 1962: 5, 60). This usage is restricted in Basse Mandinka to predicates which lean themselves for performative acts, e.g. verbs of speaking or giving:

(8) a. Na n kali!

I-YE myself swear

I swear!

b. Na i daani

I-YE you pray

I pray you / I beseech you

With a high frequency, the $Y E_{1}$ gram functions as an explicit definite past tense expressing immediate (e.g. hodiernal, 9.a), recent (e.g. hesternal 9.b), general (a person's life time 9.c) or remote (e.g. ancient 9.d) past events. This means that the activity conveyed by the $Y E_{1}$ formation may be located in a past temporal sphere, whatever its distance from the speaker's present time is:

(9) a. Na a ke bii soomandaa

I-YE it do today morning

I did it today in the morning

b. Kunun naije

yesterday I-YE you see

I saw you yesterday

c. Na ñin motoo san sanji luulu kooma

I-YE car buy year five ago

I bought the car five years ago

d. Bitun Mansa Sulemani ye Banisirayila alifaalu kumandi... then king Solomon YE Israel elders call

Then Solomon assembled the elders of Israel

Functioning as a definite past, the $Y E_{1}$ gram is frequently employed in order to convey aspectually perfective actions: unique, punctual and presented in their entirety:

(10) a. Serun ate ye kewo faa last.year he YE man kill Last year, he killed a man 

b. Kunun, na sayikuloo san
yesterday I-YE bicycle buy
Yesterday, I bought a bicycle
c. Sulemani ye Yaawe la buno ban loo la
Solomon YE Lord (Yahweh) of house finish build to
Solomon finished building the house of the Lord

Nevertheless, the $Y E_{1}$ construction may also function as an aspectually neutral simple past, i.e. as a preterite, being sometimes able to introduce activities of a wide temporal length or simply durative:

(11) a. Kunun na n don baake

yesterday I-YE myself dance very.much

Yesterday I danced a lot (cf. the use of the imperfective past bailaba in the Spanish translation)

b. Kunun na m bamban

yesterday I-YE myself be.in.a.harry

Yesterday I was in a hurry (cf. the use of the imperfective past

tenía prisa in the Spanish translation)

c. A nin ì tarata jee, anin a ye batiseeroo ke

he with them was there and he YE baptizing do

He was there with them, and he was baptizing

d. Baawo a ye ñin kuwolu ke, wo le ye a tinna ì ye a toora

Since he did this things do that EMPH did it cause ${ }^{16}$ they YE him persecute

Because he did (or had done) these things, for that reason, they

persecuted him (cf. the use of the imperfective past in the Spanish translation: perseguían)

The typical value of the perfect category, i.e. the concept of anteriority - previously discussed within the present time frame (cf. examples 3, 4, 5 and 6 above) - may also be found in the past and future temporal spheres. In the former case, the $Y E_{1}$ formation approximates a pluperfect (it expresses actions which preceded another clearly past activities; cf. examples 12a-f) while in the latter, available only in certain temporal subordinated phrases - especially in clauses which are introduced by the conjunction nin -, the gram is employed with the force of a future perfect (it expresses acts which shall take place before other situations in the future; see examples 13a-b):

(12) a. Mansa Yehowasi ye saateewolu seyinkan muta Beni-Hadadi bulu, king $Y$ did villages repeat seize $B H$ from, King Jehoash took again from the hand of Ben-hadad the cities a ye mennu muta nun a faamaa bulu he YE which seize then his father from which he had taken from the hand of his father

16 The slot wo le ye a tinna glossed as [that EMPH did it cause] corresponds to an English expression: 'for that reason'. 
b. Kabirin a ye ì la miiroolu lon, a ye ì jaabi when he YE they of thoughts know he did them answer When he had known their thoughts, he answered them...

c. Kabirin a ye ì la lannoo je, a ko: when he YE they of ${ }^{17}$ faith see he said: When he had seen their faith, he said:

d. İ ye kano laa ñin dookuulaa kuntiyo la ko a ye a la fenolu le tiñaa they did accusation present this servant chief against that he $Y E$ he of ${ }^{18}$ things EMPH spoil They accused the steward that he had wasted his [of the master] goods

e. Í muruta suwo kono, komen Alla ye a fo ñaamen they returned house in like God YE it say as They returned home according to the word of the God (i.e. as God had said it)

f. Moolu bee naata, ko a ye a fo ì ye nun ñaamen People all came like he YE it say them for then as All the people came as the king had appointed

(13) a. Saama nin i ye bukoo karan, i si n kili! tomorrow when you YE book read you shall me call Tomorrow, when you have read the book, you shall call me!

b. Sii jan fonin na a ke Sin.down here until I-YE it do Sit down here (be seated) until I have done it

The $Y E_{1}$ construction may also appear in conditional protases being, again, introduced by the conjunction nin 'if'. In that case, the formation expresses hypothetical but yet possible future events or situation which - if performed - would logically and temporarily precede actions conveyed by the apodosis. This value approximates the use of the indicative future perfect in modus realis in Latin: Site rogavero aliguid, non respondebis?' 'If I ask you something, will you not answer?' (Jurewicz et al. 1993: 128) or Si id credideris, erraveris 'If you (shall have) believe(d) that, you will have gone (will go) wrong' (Gildersleeves \& Lodge 1895: 380):

(14) a. Nin i ye motoo san, ntelu be taa la Banjunu

if you YE car buy we are go to Banjul

If you buy a car, we will go to Banjul (i.e. once you have bought the car, we will be able to go to Banjul)

b. Nin na kodoo soto, $m$ be motoo san na

if I-YE money have I am car buy to

If I have money I will buy the car (i.e. once I get some money, I will buy the car)

c. Nin Laamini ye booroo min, a be kendeyaa la le if Lamin YE medecine drink he is be.healthy to EMPH

If Lamin drinks the medicine he will be well (i.e. once he has drunk the medicine he will get well)

17 The slot i la (lit. 'they of') corresponds to a possessive adjective with the meaning of the English their.

18 The slot a la (lit. 'he of') corresponds to a possessive adjective with the meaning of the English his. 
Sometimes, the reading can be real and counterfactual. In such cases, the $Y E_{1}$ form introduces activities that refer to a present temporal sphere but portrays them as conflicting with the current state of affairs. This function corresponds to the use of the Latin coniunctivus imperfecti in the modus irrealis in the present: Si id crederes, errares 'If you believed (you do not believe but you still could), you would go wrong' (Gildersleeves \& Lodge 1895: 385):

(15) Nin ali ye wo moolu kanu, mennu ye ali kani, if you YE that people love who did you love Even though you loved people who love you (i.e. you do not love them but you still could),

wo be ali nafaa la mun ne la? that is you benefit to what EMPH at/with how would that benefit you?

The $Y E_{1}$ gram can likewise be found in conditional protases denoting past unreal counterfactual activities orsituations, thusequaling the Latin coniunctivus plusquamperfecti in the modus irrealis in the past: Si id credidisses, erravisses 'If you had believed that (but you did not), you would have gone wrong' (Gildersleeves \& Lodge 1895: 385):

(16) a. Nin ali ye nte kanu, ali be seewoo la nun if you YE me love you are be.happy to then If you (had) loved me, you would have rejoiced (but you did not love me and consequently you were not happy)

b. Nin ite ye wo ke nun, tennun nte baarinkewo te faa la nun if you YE that do then, so.then I brother is.not be.dead to then If you had done it, my brother would not have died

In cases where the $Y E_{1}$ formation is derived from certain verbs of receiving (e.g., $a$ soto 'receive, have' and a muta 'get'), perceiving (e.g., a moyi 'hear, understand' and $a$ Ion 'know') and feeling (e.g., a kanu 'love' and $a$ kon 'hate, detest'), it may denote three additional types of meaning. First, approximating a simultaneous-resultative category, it denotes a present static condition, portraying it as acquired due to a previously performed action. This value is similar to the sense offered by resultative perfects. However, the meaning of a resultative perfect displays a reverse arrangement of the two semantic planes: the most relevant segment of the meaning reflects a dynamic event which, due to its results, is in some way related to a present state of affairs.

(17) a. Fo i ye a moyi? whether you YE it hear Have you heard it? / Do you know that?

b. Na leetaroo muta I-YE letter receive I have gotten / I have got a letter 
Second, in the case where certain verbs expressing feelings (e.g. a kanu 'love' and $a$ kon 'hate') are employed in the $Y E_{1}$ gram, the value of the construction can be interpreted as stative, contrasting with more dynamic expressions formed, for instance, with the auxiliary $\mathrm{ka}$ :

(18) a. Nte ye i kanu le IYE you love EMPH I love you

b. Ate ye $n$ kon he YE me hate He hates me

And third, certain verbs when used in the $Y E_{1}$ locution introduce present activities with no evident traces of resultative (perfect or anterior) and stative shades of meaning. In this function, the construction displays an analogous force to various Indo-European simple presents:

(19) a. Na musoo soto

I-YE wife have

I have a wife

b. Na wo lon

I-YE that know

I know that

If the context locates the reference time in the past, the meaning of the $Y E_{1}$ construction, formed from the above mentioned predicates, approximates a simple or durative (imperfective) past:

(20) a. Na a lon nun

I-YE it know then

I knew that (cf. the use of the imperfective past in the Spanish translation: lo sabía)

b. Kunun a ye kodoo soto

yesterday he YE money have

He had money yesterday (cf. the use of the imperfective past in the Spanish translation tenía dinero)

The $Y E_{1}$ expression may also be found in maxims or proverbs, introducing atemporal universal truths and coexisting, in certain cases, with the habitual-iterative formation $k a+$ verbal base (cf. 21.b):

(21) a. Moo, men ye katiroo ke, a ye jooroo soto person who YE harvesting do he YE payment have receive He who reaps, receives wages 
b. Moo doo ka fiiroo ke, doo ye katiroo ke person the.one KA sowing do the.other YE harvesting do One sows and another reaps

\subsection{VALUES OF THE YE 2 FORMATION}

When used with the first person singular or plural, the $Y E_{2}$ formation approximates a cohortative gram: the subject - a person viewed as an individual or as a member of group - directs orders, suggestions or advises to him- or herself, or to the group in question. In that function, the gram has a similar force to the English expression let me or let us, Polish imperative Cieszmy się 'Let us be happy!' and to the Latin coniunctivus hortativus: Amemus patriam (Jurewicz et al. 1993: 109):

(22) a. Na dun suwo kono!

$\mathrm{I}-\mathrm{YE}$ enter house in

Let me enter into the house

b. M bula, na taa!

me leave I-YE go

Leave me, let me go!

c. Nà ñin motoo san!

we-YE this car buy

Let us buy this car!

d. Ali nà domoroo ke!

all we eating do

Let us eat!

e. Ali nà a faa!

all we-YE him kill

Let us kill him (L.20.14)

When directed to the second person plural - most frequently following an overt imperative construction - the $Y E_{2}$ formation acts as an imperative: it expresses orders, commands or suggestions directed to a single interlocutor or to a group of them:

(23) a. Wuli, i ye loo ǹ teema!

stand.up you $Y E$ stand we among

Arise and stand here in the middle of us

b. Wuli, i ye taa!

stand-up you YE go

Stand up and go!

c. Ñin kewo faa, i ye doo bula!

this man kill you YE another leave

Kill this man, leave the other! 
d. Wuli, i ye i la basoo sika, adun i ye sayi suwo kono stand.up you YE you of ${ }^{19}$ mat pick.up and you YE return house in Arise, take up your bed, and go to your house

Since orders may also be introduced by the verbal locution $s i+$ verbal base (a modal-future construction), the $Y E_{2}$ formation in the sense of an imperative frequently follows the si periphrasis:

(24) a. Ali si a samba nan, ali ye a faa you shall him bring to.here you YE him kill Bring him here and kill him!

The $Y E_{2}$ gram can also be found with the third person singular. In that case still introducing commands, suggestions and advice, the formation acts as a jussive category. In this use, it approximates the English construction with let (Let him do it!), the Polish periphrastic imperative with niech (Niech przyjdzie 'Let him come') or the Latin coniunctivus iussivus (Suum quisque noscat ingenium 'Let each one know his own mind'; Gildersleeve \& Lodge 1895: 173):

(25) a. A ye naa!

he YE come

Let him come!

b. İtolu ye taa!

they YE go

Let them go

c. N teerimaa ye a ke i ye

I friend YE it do you for

Let my friend do it for you!

In all the uses, introduced thus far, the $Y E_{2}$ construction constitutes a suppletive (with the first and third person singular and plural) or alternative (in the second person singular and plural) form of the imperative.

However, in various cases, the sense of the $Y E_{2}$ construction approximates an optative mood rather than the category which covers imperative, cohortative and jussive domains. In these cases, instead of conveying orders or suggestions, the locution expresses wishes, desires or hopes as for the present-future situation. This use has its parallels in the English construction with the verb may (May you live long! or May God help you!), in the Polish expressions with the particle oby (Oby przyszedł! 'May he come!') and in the Latin coniunctivus optativus (Stet haec urbs! 'May this city continue to stand!'; Gildersleeve \& Lodge 1895: 172):

19 The slot $i$ la (lit. 'you [sg.] of') corresponds to a possessive adjective with the meaning of the English your [singular]. 
(26) a. A ye faa!

he YE be.dead

May he day / May he be dead

b. A ye bamban!

he YE be.strong

May he be strong!

Such wishes may also be formulated as for past (presently irreversible) states of affairs. In this use, the gram approximates the coniunctivus optativus irrealis in Latin: Utinam illo tempore vixissem 'May I have lived in that time' (Jurewicz et al. 1993: 120):
A ye naa nun!
he YE come then
May he have come then!

The $Y E_{2}$ gram is also extensively employed in depending subordinated final clauses, introducing a broad spectrum of more specific values which, nevertheless, may be embraced under a single term of a purposive subjunctive: the proposition with the relevant $Y E_{2}$ form indicates intentions, goals or desires to be accomplished. It should be noted that the clause which includes a relevant $Y E_{2}$ construction may be linked to the principal clause either asyndetically (28) or by means of a conjunction, such as, fo or puru 'in order that, so that' and $k 0$ 'that' (29):

(28) a. Dalasi tan dii n na, na taa mbuuroo san na dalasi ten give me to I-YE go bread buy to Give me ten dalisis to go to buy the bread (lit. so that I may go to buy)

b. N lafita i ye kurutoo kara $n$ ye I want you YE trousers sew me for

I want you to sew trousers for me (lit. so that you may sew)

c. N lafita i ye kendeyaa

I want you YE be.healthy

I want you to be healthy (lit. so that you may be healthy)

(29) a. İ ye Laamini daani fo a ye naa jan they did Lamin ask so.that he YE come here They asked Lamin to come (lit. so that he would come

b. Nà a faa puru nà a la buno soto we did him kill so.that we-YE he of ${ }^{20}$ house have We killed him to have his house (lit. so that we would get)

c. A ye a fo $n$ ye ko na naa he did it tell I for so(that) I-YE come He told me to come (lit. so that I would come) 
The purposive final meaning can also be observed in clauses introduced by the verb ko 'say':

(30) a. A ko ga n na joobaloo joo

he said I-YE I of ${ }^{21}$ debt pay

He said [that] I should pay my debt

b. A ko i ye taa

he said you YE go

He said [that] you should go

One should also note that asyndetic purposive uses presented in examples (28.ac) and (30.a-b) are profoundly similar to the imperative-jussive-exhortative meaning found in principal clauses (cf. examples 22, 23 and 25).

\section{CONCLUSION}

The evidence provided by the interviewed Mandinka speakers in Basse and its vicinity shows that the grams formed by means of the entity ye display the following semantic load. First, as for the $Y E_{1}$ variety, the construction is used as a present perfect, offering resultative, inclusive, iterative, experiential, indefinite and performative meanings. It is also used with the force of a past tense with any degree of temporal remoteness from the speaker or narrator's present. The aspectual value of the $Y E_{2}$ locution in its definite past function is usually perfective or simple. Nevertheless, examples with a durative reading are not infrequent. The sense of anteriority prototypical for the present perfect function - may also be found in the past and (only in subordinate clauses) future time frames. In conditional phrases, the gram can introduce hypothetical eventual activities or counterfactual but yet real actions, as well as - when located in the past temporal sphere - counterfactual unreal situations. Furthermore, when derived from certain verbs of receiving, perceiving and feeling, the $Y E_{1}$ expression functions as a simultaneous-resultative, stative and simple present. With the past temporal reference, the three above-mentioned values correspond to a simultaneous-resultative, stative and simple (including durative or imperfective) past. Finally, the gram is found in proverbs with a value of a universal, atemporal or habitual present. It shall be observed that the total semantic content of the $Y E_{1}$ formation almost perfectly parallels the meanings displayed by the TA gram (cf. Andrason 2011b). The sole distinction - given the transitive nature of the $Y E_{1}$ construction and hence its incompatibility with adjectival stative verbs - is the infrequency of the simultaneousresultative or present meanings and, in particular, the properly stative value, offered with a great abundance by adjectival roots in the TA formation.

Second, in respect to the $Y E_{2}$ gram, the meaning is invariably modal. More concretely, the construction functions - depending on the person to whom a given sentence is addressed - as a cohortative ( $\left(1^{\text {st }}\right)$, imperative $\left(2^{\text {nd }}\right)$ and jussive $\left(3^{\text {rd }}\right)$. In the

21 cf. footnote 15. 
optative function, the gram may introduce real (present-future) and unreal (past) wishes and desires. In dependent final subordinate (including asyndetic) clauses, the $Y E_{2}$ form is used with the force of a subjunctive purposive category, conveying goals and intentions.

Although the results of our study grosso modo confirm the analysis available in the literature published thus far, they also provide some new facts which enable us to sketch a more complete map of the semantics of the YE grams. In particular, as for the $Y E_{1}$ construction, we have detected, until now ignored, values of performative perfect, durative past (especially in the case of dynamic action verbs), future perfect, real counterfactuality, unreal counterfactuality and universal (habitual/gnomic) present. We have furthermore offered a more meticulous description of typical perfect functions having distinguished resultative, inclusive, iterative, experiential and indefinite uses. ${ }^{22}$ Likewise, we have proposed a more detailed picture of the values displayed by verbs of reception, perception and feelings, dividing them into three domains: simultaneousresultative, stative and simple present. In respect to the $Y E_{2}$ formation, we have made a clear distinction between cohortative, jussive and imperative meanings (a suppletive or alternative form of the imperative) and optative senses. We have also shown that the optative type may be both real (wishes formulated concerning present and future situations) and unreal (desires formulated as for past, impossible to change, conditions).

We also consider that although the present analysis - dedicated to the semantic load of the constructions formed by means of the auxiliary ye - was limited to the Mandinka variety employed in Basse and neighboring villages, it can also be valuable to the study of the $Y E$ formation(s) in the standardized language. We are convinced that the values detected in our examples should likewise be available in Mandinka whether it is spoken on the sea-cost, on the northern bank of the river Gambia in Upper River Region or elsewhere in the country. In an opposite case-i.e. if some differences between the potential of the YE grams in Basse and in other areas have been detected - our description will additionally constitute an important piece of information concerning the Mandinka dialectology.

Finally, it would be highly interesting if we could unify the semantic load offered by each-one of the two YE formations. In particular, one should aim at explaining the deeply heterogeneous $Y E_{1}$ gram as a consistent and coherent semantic category where all the specific values are fully balanced and harmonized. Even more tentative - but significantly more difficult - would be the unification of the semantics of the two varieties within a single gram. These two goals inevitably constitute a future research plan of the author.

22 Such a specification is important due to the fact that perfects in various languages offer a distinct semantic load admitting or not the mentioned sub-types (cf. for instance that the Spanish present perfect he hecho 'I have done' contrary to the homologue English construction is not employed with the inclusive sense). 


\section{REFERENCES}

A Practical Orthography of Gambian Mandinka. 1988. Banjul: WEC International.

Andrason, A. 2011a. Qatal, yiqtol, weqatal y wayyiqtol. Modelo pancrónico del sistema verbal de la lengua hebrea bíblica con el análisis adicional de los sistemas verbales de las lenguas acadia y árabe [Qatal, yiqtol, weqatal and wayyiqtol - a panchronic model of the Biblical Hebrew verbal system with an additional analysis of the Akkadian and Arabic verbal systems]. Madrid: Publicaciones de Universidad Complutense.

Andrason, A. 2011b. Semantics of the ta construction in Basse Mandinka. Linguistica Copernicana 6, 223-246.

Andrason, A. forthcoming. Introducción a la gramática descriptiva del mandinka de la región de Basse.

Austin, J. L. 1962. How to Do Things with Words. Oxford: Clarendon Press.

Colley, S. 1995. Mandinka Grammar Manual. Banjul: Peace Corps The Gambia.

Creissels. D. 1983. Eléments de grammaire de la langue mandinka. Grenoble: ELLUG.

Creissels, D. 2007. A sketch of Bambara argument structure. Workshop Grammar and Processing of Verbal Arguments. Leipzig, April 20-21, 2007.

Creissels, D. 2008. L'incorporation en mandinka. In D. Amiot (ed.) La composition dans une perspective typologique. Artois: Artois Presses Université, 75-88.

Creissels, D. 2010a. Transitivity alternations in Mandinka. Workshop on Valency Classes. Leipzig, August 21, 2010.

Creissels, D. 2010b. The flexibility of the noun vs. verb distinction in the lexicon of Mandinka. International Conference on Polycategoriality. Paris, October 4-6, 2010.

Creissels, D. 2011. Leipzig Valency Classes Project: Mandinka corpus. [Internet]. Available at: http://www.deniscreissels.fr/public/Creissels-valency_classes_project_Mandinka. pdf [03.08.2012].

Dramé, M. 2003. Parlons mandinka. Paris: L'Harmattan.

Gamble, D. 1987. Elementary Mandinka (Gambian Studies 20). San Francisco: Gamble.

Gildersleeve, B. L. \& G. Lodge. 1895. Gildersleeve's Latin Grammar. London: Macmillan and $\mathrm{Co}$.

Jurewicz, 0., L. Winniczuk \& J. Żuławska. Język łaciński. Warszawa: PWN.

Kamben Kotoo (Old Testament). 1998. Banjul: WEC International.

Kamben Kutoo (New Testament). 1989. Banjul: WEC International.

Kastenholz, R. 1996. Sprachgeschichte im West-Mande: Methoden und Rekonstruktionen. Köln: Rüdiger Köppe Verlag.

Lewis, M. P. (ed.). 2009. Ethnologue: Languages of the World, Dallas: SIL International.

Long, R. W. 1971. A Comparative Study of Northern Mande Languages. Ann Arbor, Michigan: Indiana University Microfilms.

Macbrair, R. M. 1842. A Grammar of the Mandingo Language. London: The WesleyanMethodist Missionary Society.

Mandinka English Dictionary. 1988. Banjul: WEC International.

Mandinka English Dictionary. Revised edition. 1995. Banjul: WEC International.

Mandinka Learning Manual. 2002. Banjul: WEC International.

Rowlands, E. C. 1959. A grammar of Gambian Mandinka. London: SOAS. 
Selections from the Writings of the Promised Messiah. 1988. Tilford: Islam International Publications LTD.

Spears, R. 1965. The structure of Faranah Mandinka. Ann Arbor, Michigan: Indiana University Microfilms.

Tera, K. 1979. Le manding: situations et usages officiels. In Documents de la réunion d'experts sur l'utilisation des langues africaines régionales ou sous-régionales comme véhicule de culture et moyen de communication dans le continent. Bamako: UNESC0, 119-123.

Vydrine, V., T.G. Bergman \& M. Benjamin. 2000. Mandé language family of West Africa: Location and genetic classification (SIL Electronic Survey Report). Dallas: SIL International.

Williamson, K. \& R. Blench. 2000. Niger-Congo. In B. Heine \& D. Nurse (eds.) African Languages. Cambridge: CUP, 11-42.

Wilson, W. 2000. Creissels's Mandinka Grammar. Journal of West African Languages 28 (2), 109-124.

\section{SUMMARY}

\section{THE MEANING OF THE YE CONSTRUCTIONS IN BASSE MANDINKA}

The present paper analyzes the semantic load of grams formed by means of the entity ye in the Mandinka variety spoken in Basse and neighboring villages in the easternmost part of Gambia. Such constructions may be divided into two classes: $Y E_{1}$ and $Y E_{s}$ types. As for the $Y E_{1}$ variety, our evidence demonstrates that the construction is used as a present perfect (resultative, inclusive, iterative, experiential, indefinite and performative), past tense (perfective, simple and durative), pluperfect and future perfect. In conditional phrases, the formation introduces three sorts of meaning: hypothetical eventual activities, counterfactual but yet possible actions and unreal counterfactual past situations. When derived from certain verbs of receiving, perceiving and feeling, it functions as a simultaneous-resultative, stative and simple present and past. It is also found in proverbs with the value of a universal or habitual present. In respect to the $Y E_{2}$ gram, the meaning is invariably modal. The construction functions as a cohortative, imperative and jussive. The gram may also display real (present-future) and unreal (past) optative meanings. In dependent final subordinate clauses, the $Y E_{2}$ form is used with the force of a subjunctive purposive category, expressing goals and intentions.

KEYWORDS: African linguistics, Mande family, Manding tongues, verbal system, semantics.

(Original scientific paper received 17.01.2012;

revised 14.12.2012;

accepted 17.12.2012) 